\title{
Sensitization of $\operatorname{Pr}(\mathrm{III})$ ions in porous material via an antenna effect
}

\author{
Melek ÖZDAŞ BÜTÜN* \\ Ballkesir University Faculty of Science and Arts, Department of Physics, Cagis Campus, Balikesir. \\ Geliş Tarihi (Recived Date): 17.08.2017 \\ Kabul Tarihi (Accepted Date): 17.11.2017
}

\begin{abstract}
Metal organic frameworks (MOF) are porous materials which generally construct with ligands and metal ions. Recently, most of studies in the field of photoluminescence properties of Ln(III) complexes has been focused on Eu(III), Tb(III), Dy(III) and Sm(III) compounds. In according to our research; investigation of luminescence properties of specially $\operatorname{Pr}(I I I)$ complexes are limited report in literature. In this study, $\operatorname{Pr}(I I I)$ metal ion has been selected to form the metal organic frameworks. Because of forbidden $f-f$ transitions, direct excitation of lanthanide (III) ions is nearly impossible. The sensitization of organic ligands is more effectively achieved a via antenna effect. To obtain excellent luminescence properties, the significant design or selection of a suitable ligand play a key role in the building of 3D-MOFs. In this work, luminescence characteristics of the Pr-MOF complex both in visible and NIR region and energy transfer mechanism have been investigated.
\end{abstract}

Keywords: Metal organic framework, porous material, praseodymium(III), photoluminescence, antenna effect.

\section{Gözenekli malzemelerde $\operatorname{Pr}(\mathrm{III})$ iyonlarının anten etkisi ile duyarlılaştırılması}

\section{Özet}

Metal organik çerçeveler (MOÇ) genellikle ligandlar ve metal iyonlar ile oluşturulan gözenekli malzemelerdir. Son zamanlarda, Ln(III) komplekslerinin fotolüminesans özellikleri alanında yapılan çalışmaların çoğu Eu(III), Tb(III), Dy(III) ve Sm(III) komplekslerine odaklanmıştır. Araştırmalarımıza göre; özellikle Pr(III) komplekslerinin lüminesans özelliklerinin incelenmesi üzerine yapılan çallşmalar literatürde sinırlıdır. Bu çalışmada, metal organik çerçeve elde etmek için Pr(III) metal iyonu seçilmiştir. f-f geçişlerinin yasaklı olması nedeniyle, lantanit (III) iyonlarının doğrudan uyarılması hemen hemen mümkün değildir. Organik ligandların sağladı̆̆ı anten etkisiyle lüminesans artışı daha etkili bir şekilde elde edilir. Uygun bir ligandın seçimi veya anlamlı tasarımı, mükemmel lüminesans özelliklerini elde etmek için 3 boyutlu MOÇ'lerin oluşturulmasında önemli bir rol oynamaktadır. Bu çalışmada Pr-MOÇ kompleksinin hem görünür hem de NIR bölgedeki lüminesans karakteristiği ile enerji transfer mekanizması incelenmiştir.

Anahtar Kelimeler: Metal organik çerçeve, gözenekli materyal, praseodim (III), fotolüminesans, anten etkisi.

\footnotetext{
*Melek ÖZDAȘ BÜTÜN, melekozdas@baun.edu.tr, https://orcid.org/0000-0002-5369-8292
} 


\section{Introduction}

Porous coordination polymers (PCPs) or Metal Organic Frameworks (MOFs) have recently become a popular study area in material research $[1,2]$. These porous framework structures are synthesized from the metal ions and organic bridge ligands via coordination bonds. Generally, aromatic polycarboxylates are favoured to other organic ligands because they generate robust three dimensional (3D) frameworks with interesting porous properties and large aperture loops [3]. Furthermore, polycarboxylate anions are suitable bridging ligands for constructing porous metal organic frameworks which can find lots of potential application areas (Scheme 1) [4-7]. Also, lanthanide cations have larger ionic radius and higher coordination numbers than transition metals and they can be coordinated with numerous organic ligands that lead to different topologies [8].

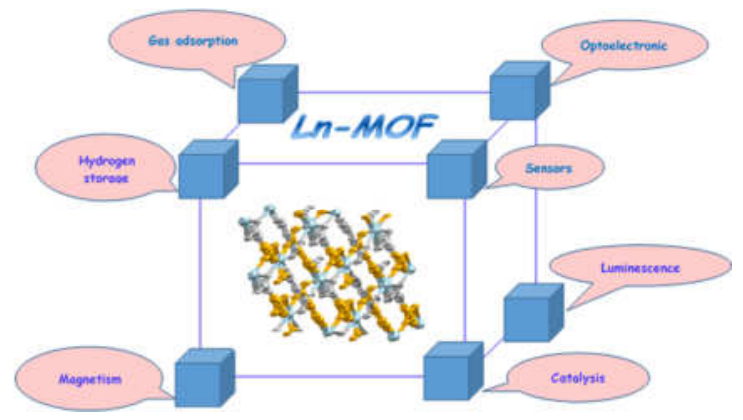

Scheme 1. Application areas of porous metal organic frameworks.

Hydrothermal technique is well suited to the preparation of crystals of new inorganic materials, porous coordination polymers and metal organic frameworks [9]. The starting $\mathrm{pH}$ and reaction temperature value have critic importance for to obtaining porous coordination polymers under hydrothermal conditions. Especially the $\mathrm{pH}$ is the most important parameter of the controlling the number of free carboxylic acid functions of the organic ligand.

Porous framework structures which contains lanthanide ions have sensitize luminescence when they excited via antenna effect. This effect come true with using suitable organic ligand as a sensitizers to obtain energy transfer from ligand to metal with indirect pathway and this way lanthanide ions may exhibit intense luminescence. Herein, 1, 2, 4,5 - benzene tetracarboxylic acid $\left(\mathrm{H}_{4} \mathrm{btec}\right)$ was used as main sensitizer for $\operatorname{Pr}(\mathrm{III})$ ions in complex $\mathbf{1}$. In this study, crystal structure of $\left[\mathrm{Pr} \bullet 2(\mathrm{btec})_{1 / 2} \bullet(\mathrm{H} 2 \mathrm{O})\right]_{\mathrm{n}}$ (1) porous 3D metal organic framework was obtained using hydrothermal technique and characterized by IR, UV-Vis, photoluminescence spectroscopy and $\mathrm{X}$-ray single crystal analysis. This complex had been already reported as only structural properties [10].

\section{Experimental}

\subsection{Materials and physical measurements}

Praseodymium(III) nitrate hexahydrate and 1, 2, 4, 5- benzene tetracarboxylic acid were purchased from Sigma-Aldrich and used without further purification. Elemental $(\mathrm{C}, \mathrm{H})$ analyses were determined with a LECO, CHNS-932 analyzer. FT-IR spectrum were recorded with a Perkin-Elmer Spectrum 65 instrument in the range of $4000-600 \mathrm{~cm}^{-1}$. Powder $\mathrm{X}$-ray measurements were performed using $\mathrm{CuK}_{\alpha}$ radiation $(\lambda=1.5418 \AA)$ on a Bruker-AXS D8Advance diffractometer equipped with a secondary monochromator. The data were collected in the range $5^{\circ}<2 \theta<50^{\circ}$ in $\theta-\theta$ mode with a step time of ns $(5 \mathrm{~s}<\mathrm{n}<10 \mathrm{~s})$ and step width of $0.017^{\circ}$. Solid state UV-visible spectra were measured with an Ocean Optics Maya 2000Pro Spectrophotometer at room temperature. Solid state photoluminescence spectra in both the visible and NIR region were measured at room temperature with an ANDOR SR500i-BL Photoluminescence Spectrometer. The measurements were carried out using the excitation source $(349 \mathrm{~nm})$ of a Spectra-physics Nd:YLF laser as a source.

\subsection{Synthesis of complex 1}

Complex 1 was hydrothermally synthesized from a mixture of benzene-1, 2, 4, 5-tetracarboxylic acid $\left(\mathrm{H}_{4}\right.$ btec $) \quad(0.15$ mmol, $0.038 \mathrm{~g}), \operatorname{Pr}\left(\mathrm{NO}_{3}\right)_{3} \cdot 6\left(\mathrm{H}_{2} \mathrm{O}\right)$ $(0.15 \mathrm{mmol}, 0.065 \mathrm{~g})$, an aqueous solution of $\mathrm{NaOH}$ $(0,65 \mathrm{M}-0,5 \mathrm{ml})$ and $20 \mathrm{ml}$ distilled water. The reaction mixture was added to a $45 \mathrm{~mL}$ Parr-Teflon lined stainless steel vessel (while $\mathrm{pH}$ 5). The vessel sealed and heated at $160{ }^{\circ} \mathrm{C}$ for $4 \mathrm{~d}$. After the reaction, greenish colorless crystals were obtained which were filtered off and washed with cold distilled water, and then single crystals of complex were collected and dried in air. $\mathrm{C}_{10} \mathrm{H}_{5} \mathrm{PrO}_{9}$ : $\mathrm{C}$, 29.29; H, 1.23; Found: C, 29.13; H, 1.36 IR $\left(\mathrm{cm}^{-1}\right)$ 1594 (w), 1525 (s), 1491 (s),1379 (s), 1326 (w), $1299(\mathrm{w}), 1241(\mathrm{w}), 1194(\mathrm{w}), 1144(\mathrm{~m}), 944(\mathrm{w})$, $892(\mathrm{w}), 863(\mathrm{~m}), 813$ (s), $764(\mathrm{~m}), 723(\mathrm{w}), 713$ (w), $660(\mathrm{w}), 617(\mathrm{w})$.

\section{3. $\quad X$-ray structure determination}

$\mathrm{X}$-ray diffraction data of the complex $\mathbf{1}$ were collected on a Xcalibur, Eos diffractometer using $\mathrm{MoK}_{\alpha}$ radiation at room temperature $(293 \mathrm{~K})$. Structure of complex $\mathbf{1}$ was solved by direct methods using SHELXS [11] and refined by full-matrix least-squares based on $\left|F_{\text {obs }}\right|^{2}$ using SHELXL with OLEX2 program [12]. The detailed hydrogen bonding and supramolecular interactions were calculated with PLATON 1.16 
program [13]. Molecular graphics were achieved using OLEX2 and MERCURY [12, 14].

Table 1. Single crystal data and refinement parameters for complex 1.

\begin{tabular}{|c|c|}
\hline Chemical Formula & $\mathrm{C}_{10} \mathrm{H}_{5} \mathrm{PrO}_{9}$ \\
\hline $\mathrm{M}_{\mathrm{w}}$ & 410.05 \\
\hline Crystal system , & Triclinic, $P-1$ \\
\hline Unit cell dimensions & $\begin{array}{ccc}a=6.3892(4) & \AA & \alpha=88.438(6)^{\circ} \\
b=9.3530(7) & \AA & \beta=74.414(6)^{\circ} \\
c=9.5444(7) & \AA & \gamma=76.692(6)^{\circ}\end{array}$ \\
\hline $\mathrm{V}\left(\AA^{3}\right)$ & $534.27(7) \AA^{3}$ \\
\hline$Z$ & 2 \\
\hline$\rho_{\text {calc }}\left(\mathrm{g} \mathrm{cm}^{-3}\right)$ & 2.549 \\
\hline$\mu\left(\mathrm{mm}^{-1}\right)$ & 4.608 \\
\hline$\theta_{\min }-\theta_{\max }\left({ }^{\circ}\right)$ & $3,2^{\circ}-26,4^{\circ}$ \\
\hline $\mathrm{h}, \mathrm{k}, \mathrm{l}$ range & $\begin{aligned}-7 & \leq h \leq 7 \\
-11 & \leq k \leq 11 \\
-11 & \leq l \leq 6\end{aligned}$ \\
\hline $\begin{array}{l}\text { Number of Collected, } \\
\text { Independent, } \\
\text { Observed Reflection }\end{array}$ & $\begin{array}{c}2865 ; 2147\left(\mathrm{R}_{\mathrm{int}}=0,025\right) ; 1960[I> \\
2 \sigma(I)]\end{array}$ \\
\hline$S$ & 1.05 \\
\hline$R_{l}\left[F^{2}>2 \sigma\left(F^{2}\right)\right]$ & 0.028 \\
\hline$w R\left(F^{2}\right)$ & 0.054 \\
\hline
\end{tabular}

The crystallographic data and refinement parameters for complex $\mathbf{1}$ are listed briefly in Table 1. Selected geometric parameters and possible hydrogen bond geometry $\left(\AA,{ }^{0}\right)$ are summarized in Table 2 and Table 3 , respectively.

Table 3. Hydrogen bond geometry for complex $\mathbf{1}$.

\begin{tabular}{|c|c|c|c|c|c|}
\hline $\mathbf{D}-\mathbf{H}^{\cdots} \mathbf{A}^{*}$ & $\begin{array}{c}\mathrm{D}- \\
\mathrm{H}\end{array}$ & $\mathbf{H}^{\cdots} \mathbf{A}$ & $\mathbf{D} \cdots \mathbf{A}$ & $\begin{array}{c}\text { D - } \\
\mathbf{H}^{\cdots} \mathbf{A} \\
\end{array}$ & Symmetry \\
\hline $\begin{array}{c}\mathrm{O}^{\text {iii }}- \\
\mathrm{H}^{\mathrm{in}} \mathrm{B}^{\cdots} \mathrm{O}^{\mathrm{iv}}\end{array}$ & 0.86 & 2.10 & $2.930(5)$ & 162 & $2-x, 2-y,-z$ \\
\hline $\begin{array}{c}\mathrm{O} 7^{\mathrm{vii}}- \\
\mathrm{H} 7^{\cdots}{ }^{\text {viii }}\end{array}$ & 0.82 & 1.78 & $2.581(5)$ & 166 & $2-x, 1-y, 1-z$ \\
\hline $\begin{array}{c}\text { C3 - } \\
\text { H3 } \cdots \text { O9 }\end{array}$ & 0.93 & 2.45 & $2.773(5)$ & 100 & $\mathrm{x}, \mathrm{y}, \mathrm{z}$ \\
\hline $\begin{array}{c}\mathrm{C} 8- \\
\mathrm{H} 8 \cdots \mathrm{O} 7 \\
\end{array}$ & 0.93 & 2.34 & $2.688(6)$ & 102 & $\mathrm{x}, \mathrm{y}, \mathrm{z}$ \\
\hline
\end{tabular}

$\mathrm{z}$; (viii) $-1+\mathrm{x},-1+\mathrm{y}, \mathrm{z}$ ]

Table 2. Selected geometric parameters for complex $\mathbf{1}$.

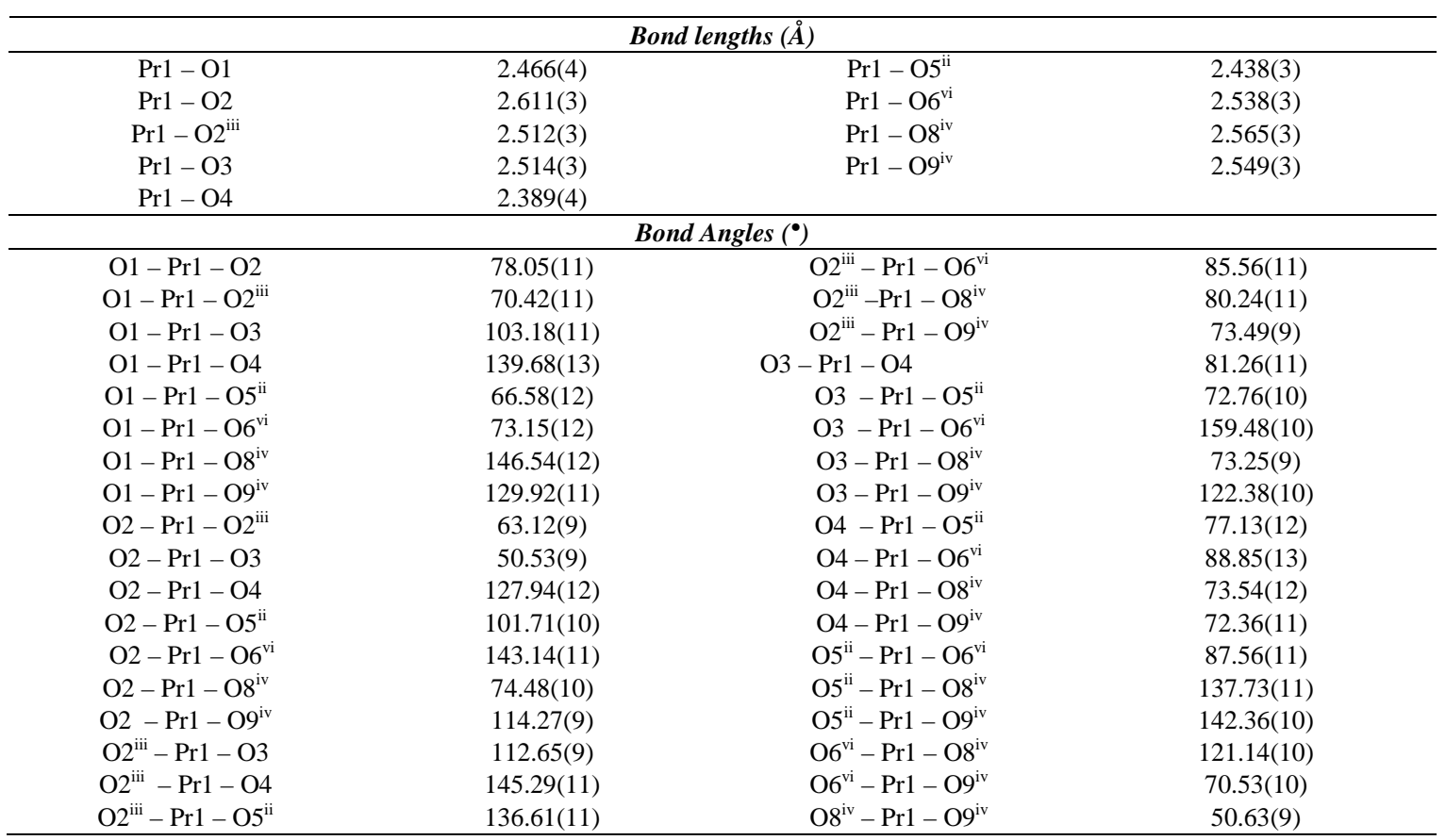

[Symmetry code(s): (ii) 1-x, 1-y, 1-z ; (iii) 2-x,1-y,-z ; (iv) x, -1+y, z ; (vi) 2-x, -y, 1-z ]

\section{Result and discussion}

\subsection{X-ray structure determinations of Complex 1}

In this study, a $\operatorname{Pr}^{\mathrm{III}}$ based metal organic framework (1) has been successfully synthesized by hydrothermal technique. Its crystal structure has been determined by single crystal X-ray diffraction analysis. Complex 1 crystallizes in triclinic space group P-1 and possesses a 3D coordination framework. The asymmetric unit of $\mathrm{Pr}$ complex consists of one $\operatorname{Pr}(\mathrm{III})$ ion, two half btec ligand and one coordinated water molecule. The Fig. 1 is a part of representation of crystal structure of 
$\left[\mathrm{Pr} \bullet 2(\mathrm{btec})_{1 / 2} \bullet(\mathrm{H} 2 \mathrm{O})\right]$ with atom labeling. As is also understood from the Fig. 1, two crystallographic inversion center come across with the center of two btec aromatic ring. The four carboxyl groups of the btec anion take two different coordination modes $\left(\eta^{8} \mu_{4}, \eta^{6} \mu_{6}, \eta\right.$ : number of coordination bond, $\mu$ : number of bonded metal) (Scheme 2). In complex 1, there is a carboxyl group of the $\mathrm{H}_{4}$ btec is deprotonated, in good agreement with the IR spectral data since absence of the band around 1700 $\mathrm{cm}^{-1}$ for $-\mathrm{COOH}$ was observed. Pr ions linked by bridging carboxylate groups, to generate a $1 \mathrm{D}$ chain with $\operatorname{Pr}{ }^{\cdots} \operatorname{Pr}$ distances of 4.366 and $5.901 \AA$, respectively (Fig. 2). Also coordination environment of each Pr ion complete with six btec ligand and one water molecule to reach nine coordination (Fig. 3a). Fig. 3b illustrates of polyhedral geometry of $\operatorname{Pr}($ III) ions called distorted monocapped square-antiprism. Furthermore, each btec ligand links four Pr(III) centers to form a 2D network. Then the 2D networks are further linked by btec ligand, to generate a porous 3D framework structure (Fig. 4).

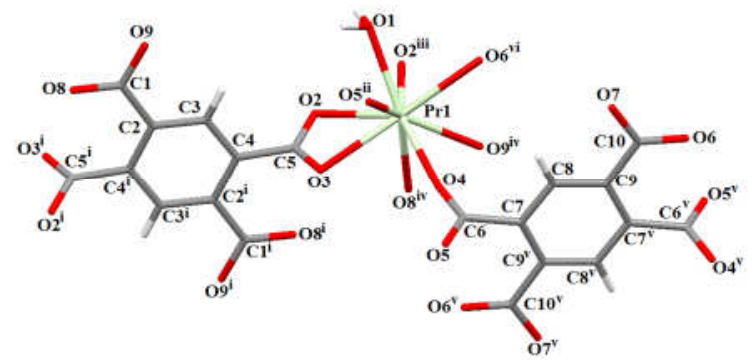

Figure 1. Part of representation of crystal structure of $[\mathrm{Pr} \bullet 2$ (btec) $1 / 2 \bullet(\mathrm{H} 2 \mathrm{O})]$. [Symmetry code(s): (i) 1 $\mathrm{x}, 2-\mathrm{y},-\mathrm{z}$; (ii) 1-x, 1-y, 1-z; (iii) 2-x, 1-y, -z; (iv) $\mathrm{x}$, $-1+\mathrm{y}, \mathrm{z}$; (v) 1-x, -y, 1-z; (vi) $-\mathrm{x}+1,-\mathrm{y}+2,-\mathrm{z}+2$ ]
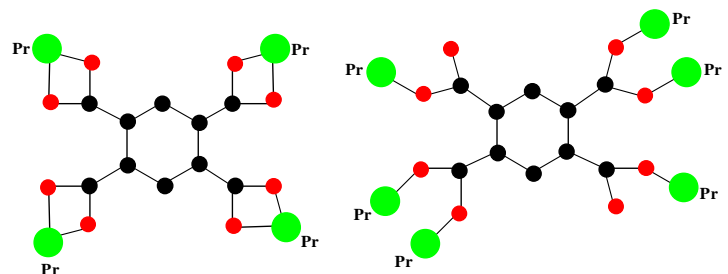

Scheme 2. Coordination modes of btec ligand in Complex 1.

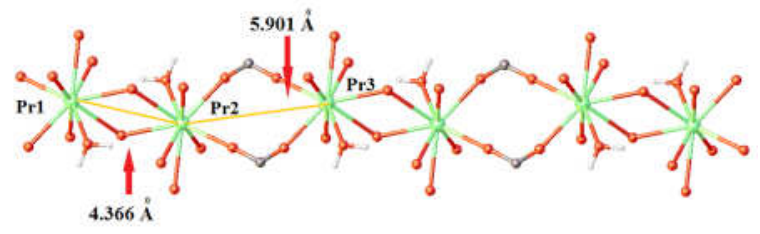

Figure 2. A view of 1D chain of complex 1 which illustrates $\operatorname{Pr}-\operatorname{Pr}$ distances.
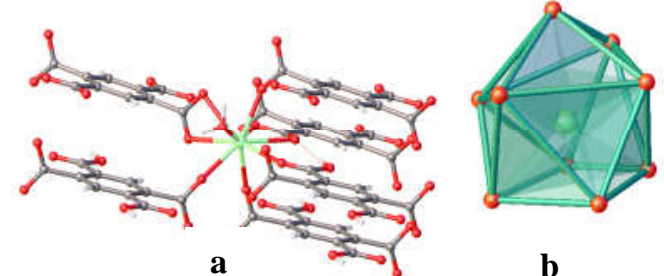

b

Figure 3. Representation of the (a) coordination environment and (b) polyhedra of Pr ion.

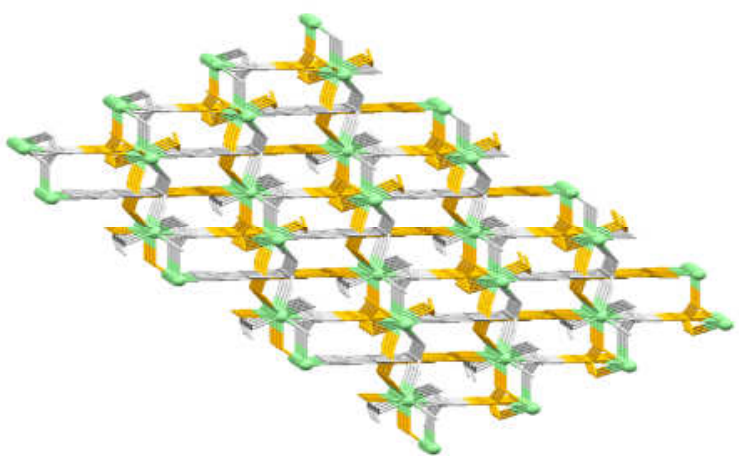

Figure 4. Illustrations of the 3D porous coordination network of complex 1.

\subsection{FT-IR spectra}

The IR spectrum of the complex $\mathbf{1}$ was given in Fig. 5. The absence of the band at about $1700 \mathrm{~cm}^{-1}$ $[v(\mathrm{C}=\mathrm{O})]$ which exist in the $\mathrm{H}_{4}$ btec ligand for complex $\mathbf{1}$ is originated from deprotonation of the ligand in the complex [15]. The absorption bands due to the asymmetric $\left[v_{\text {asym }}(\mathrm{COO})\right]$ and symmetric $\left[v_{\text {sym }}(\mathrm{COO})\right]$ vibration of carboxylate were observed between 1594 and $1326 \mathrm{~cm}^{-1}$ for complex 1[16].

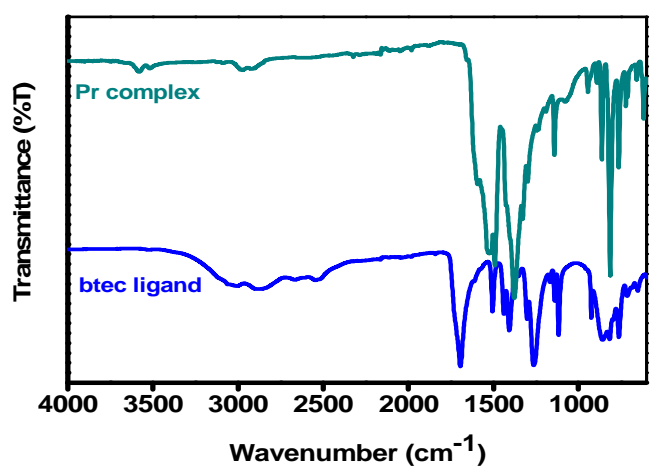

Figure 5. FT-IR spectra of free btec ligand and Complex 1.

There is no band at about $3400 \mathrm{~cm}^{-1}[v(\mathrm{O}-\mathrm{H})]$ because of no lattice water molecule in the complex. The $\rho_{\mathrm{r}}\left(\mathrm{H}_{2} \mathrm{O}\right)$ vibration at about $660 \mathrm{~cm}^{-1}$ in complex 1 is originated from coordinated water molecule $[17,18]$. The IR results are in agreement with the crystallographic parameters. 


\subsection{Solid state $U V$-Vis spectra}

The UV-Vis absorption spectra of the free ligand and complex 1 were determined in the solid state at room temperature and illustrated in the Fig. 6. The absorption spectra of the free ligand exhibits broad band and it can be assigned to the singlet-singlet $\pi-\pi^{*}$ transitions with maximum at $395 \mathrm{~nm}[19,20]$. Whereas free $\mathrm{H}_{4}$ btec exhibited a broad absorption band with maximum owing to the $\pi-\pi^{*}$ transitions, complex 1 showed broad band at about $490 \mathrm{~nm}$. In complex 1, lower energy absorption at $490 \mathrm{~nm}$ than in the $\mathrm{H}_{4}$ btec ligand could be assigned by virtue of ligand to metal charge transfer transitions from oxygen atoms to $\operatorname{Pr}(\mathrm{III})$ atoms [21]. Broad bands ranging from 400 to $500 \mathrm{~nm}$ originate in the electronic transitions from the bonding orbitals to the non-bonding orbitals. This transition is prohibited, and consequently, the absorption intensity in the visible region is lower than that of the absorption in the UV region originated from the transitions from the bonding orbitals to the antibonding orbitals [22].



Figure 6: UV-Visible spectras of btec ligand and complex 1 as solid state.

\subsection{Photoluminescence Properties}

Upon excitation at the $349 \mathrm{~nm}$, the solid-state photoluminescence properties of the btec ligand and complex $\mathbf{1}$ were investigated at room temperature in the visible and NIR regions. The emission spectrum of the ligand in visible region, displayed an emission band with a maximum wavelength of $480 \mathrm{~nm}$. Accordingly, the ligand showed blue emission as conform with its maximum wavelength (Fig. 7). For Pr (III) in complex 1, there were obtained two possible emitting $f$ states ${ }^{3} \mathrm{Pj}(\mathrm{j}=0,1,2)$ and ${ }^{1} \mathrm{D}_{2}$ for visible and NIR region, respectively. The emission spectrum of complex $\mathbf{1}$ in visible region upon excitation at $349 \mathrm{~nm}$ exhibited three characteristic transition with peaks at 456, 478, and $501 \mathrm{~nm}$ (Fig. 8a), respectively corresponding to the transitions of Pr(III) from ${ }^{3} \mathrm{P}_{2} \rightarrow{ }^{3} \mathrm{H}_{4},{ }^{3} \mathrm{P}_{1} \rightarrow{ }^{3} \mathrm{H}_{4}$, and ${ }^{3} \mathrm{P}_{0} \rightarrow{ }^{3} \mathrm{H}_{4}$ [23]. The residual emissions from the $\mathrm{H}_{4}$ btec ligand have located in the wavelength region of 400-450 $\mathrm{nm}$, which can be attributed to the phosphorescence of the ligand [24]. And also complex 1 showed more three characteristic emissions at about $866 \mathrm{~nm}$, $1081 \mathrm{~nm}, 1503 \mathrm{~nm}$ in NIR region, which assigned to ${ }^{1} \mathrm{D}_{2} \rightarrow{ }^{3} \mathrm{~F}_{2},{ }^{1} \mathrm{D}_{2} \rightarrow{ }^{3} \mathrm{~F}_{4}$ and ${ }^{1} \mathrm{D}_{2} \rightarrow{ }^{1} \mathrm{G}_{4}$ transitions of the Pr3+ ion, respectively (Fig. 8b) [25- 27]. The emitting bands around $1081 \mathrm{~nm}$ arise from ${ }^{1} \mathrm{D}_{2}$ not ${ }^{1} \mathrm{G}_{4}$ level, in that the ${ }^{1} \mathrm{G}_{4} \rightarrow{ }^{3} \mathrm{H}_{5}$ emission around 1320 $\mathrm{nm}$ was not observed, referring nonradiative process with phonon assistance predominates relaxation of ${ }^{1} \mathrm{G}_{4}$ manifold energy levels. It is significant to obtain the NIR luminescence of $\operatorname{Pr}(\mathrm{III})$ ion, since the $\operatorname{Pr}(\mathrm{III})$ ion can show emissions from three different levels $\left({ }^{3} \mathrm{P}_{0},{ }^{1} \mathrm{D}_{2}\right.$ and $\left.{ }^{1} \mathrm{G}_{4}\right)$ when excitation [25].

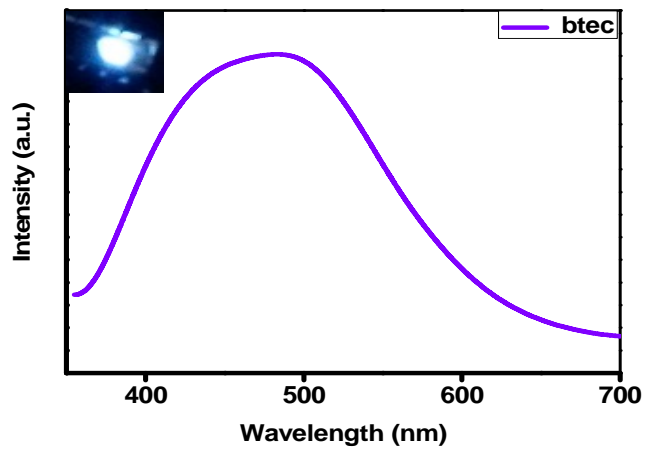

Figure 7. Visible emission spectra of free btec ligand.

\subsection{Sensitization of $\operatorname{Pr}($ III) ions and Energy Transfer Mechanism}

In general, the sensitization process of the organic ligands for lanthanide ions can be expounded as following;

i. Firstly, the ligands absorb energy in the UV region and a few electrons from singlet ground state $\left(\mathrm{S}_{0}\right)$ would stimulated to the first excited singlet state $\left(S_{1}\right)$,

ii. Then they pass to the lowest triplet excited state $\left(\mathrm{T}_{1}\right)$ via intersystem crossing which is a radiationless transition,

iii. Afterwards energy is transferred through interbond coupling to the lowest excitation state of lanthanide ions,

iv. Finally, the excited electrons turn back to the ground state, thereby emitting the characteristic intensive luminescence of lanthanide ions.

The chromothographic ligands act a role of antenna by the way of transferring energy efficiently to central $\operatorname{Ln}(\mathrm{III})$ ions and this process called as antenna effect (Fig. 9) [28]. In the present study, upon indirect sensitization of the $\operatorname{Pr}(\mathrm{III})$ emission using by $\mathrm{H}_{4}$ btec ligand via antenna effect, complex 1 exhibit intense sensitive photoluminescence emission behavior both visible and NIR region. Energy transfer paths in complex 1 with Jablonski diagram is given Fig. 11. Researchers have suggested an idea for determination of antenna effect by examination of spectrum as the overlaps between 
the excitation spectrum of complex and the absorption spectra of its corresponding ligands (Fig. 10) [29- 31] .
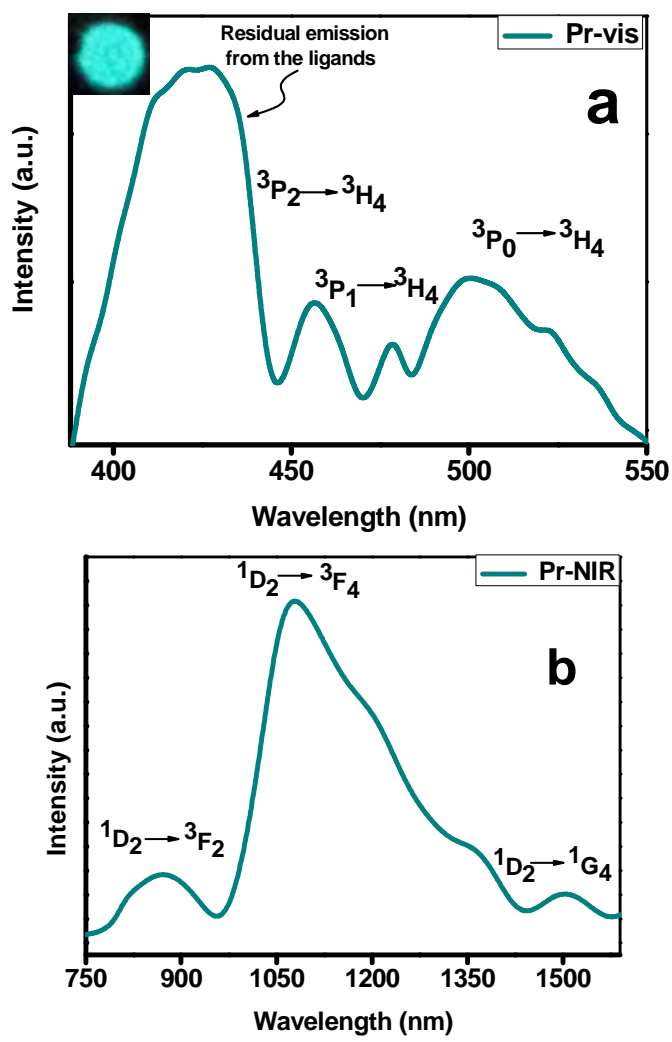

Figure 8. The emission spectrum of complex $\mathbf{1}$ in solid samples at room temperature $\left(\lambda_{\mathrm{ex}}=349 \mathrm{~nm}\right)$. (a) visible, (b) near-infrared region (range of 750$1600 \mathrm{~nm}$ ) [Upper-left photos in figures are photoluminescent images of compounds while excited at $349 \mathrm{~nm}$ ]

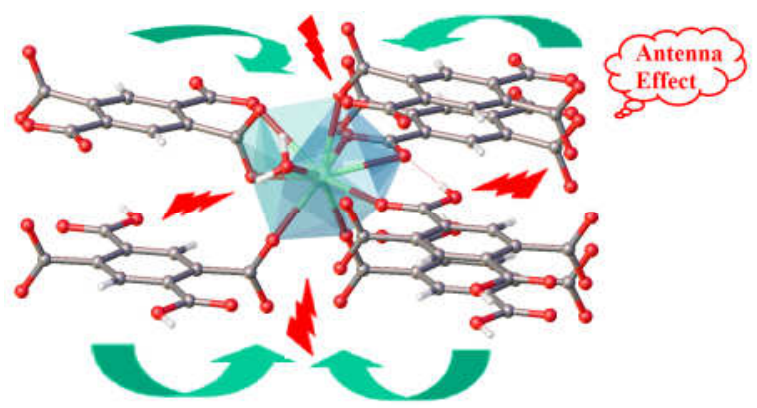

Figure 9. Schematic diagram of the Antenna Effect

When photoluminescence emission spectra of complex $\mathbf{1}$ are examined, a broad band emission except three characteristic transitions is observed belong to ligand centered emission in the visible region. Energy transfer from ligand to metal has not actualized effectively in the relevant region. However, obtaining the three for each characteristic transitions both in visible and NIR region show that increase the sensitization of $\operatorname{Pr}(\mathrm{III})$ ions.

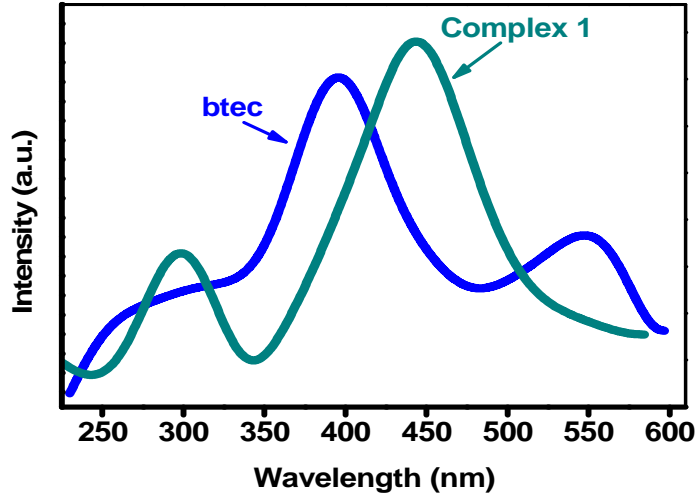

Figure 10. Overlapping of absorption spectrum of the free and excitation spectra of Complex 1 (All spectra are normalized to a constant intensity at the maximum).

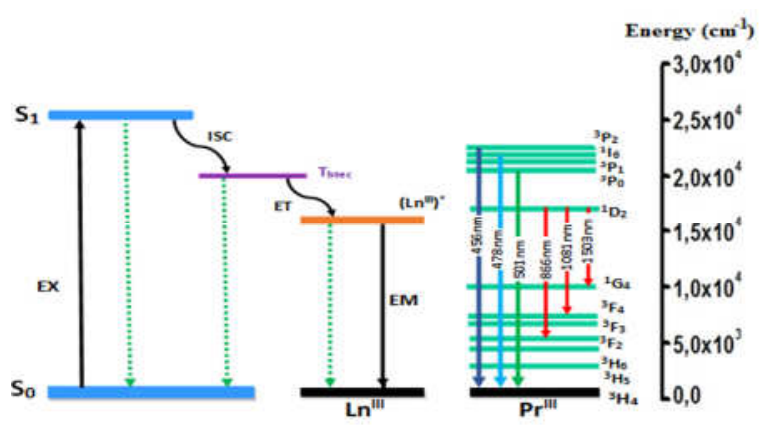

Figure 11. Energy transfer paths in Complex 1.

\section{Conclusion}

The content of this study relates to the synthesization, crystal structure analysis and photosensitization of visible and near-infrared luminescent $\operatorname{Pr}(\mathrm{III})$ complex. A porous lanthanide complex $[\mathrm{Pr} \bullet 2(\mathrm{btec}) 1 / 2 \bullet(\mathrm{H} 2 \mathrm{O})]$ have been successfully synthesized by hydrothermal technique using $\mathrm{H}_{4}$ btec ligand as oxygen donor. Its structure was well characterized by FT-IR, UV-Vis absorption spectroscopy and single-crystal X-ray diffraction. Organic bridge ligand and $\operatorname{Pr}(\mathrm{III})$ ions for the complex 1 clustered to generate a porous 3D framework structure and formed a structure which has nine coordination encircled the $\operatorname{Pr}(\mathrm{III})$ atom. Photoluminescence properties of the complex 1 were studied upon laser excitation at $349 \mathrm{~nm}$ as a solid at room temperature. The results of luminescence investigations showed intense and characteristic photoluminescence emissions from the $f-f$ transitions for complex $\mathbf{1}$ both visible and NIR region, mentioned $\mathrm{H}_{4}$ btec ligand effectively sensitized the luminescence of $\operatorname{Pr}(\mathrm{III})$ ions through the energy transfer from the ligands to metal atom. The results obtained from this study not only enriched the structures of porous organic frameworks with lanthanides, but also showed 
special interesting photophysical properties arising from the lanthanide metal ions.

\section{Acknowledgements}

The author thanks to the Research Funds of Balikesir University (BAP-2016/105) for the financial support and to Dokuz Eylül

\section{References}

[1] Stock, N. and Biswas, S., Synthesis of MetalOrganic Frameworks ( MOFs): routes to various MOF topologies, morphologies, and composites, Chemical Review, 112, 933969, (2012).

[2] Lincke, J., Lässig, D., Moellmer, J., Reichenbach, C., Puls, A., Moeller, A., Gläser, R., Kalies, G., Staudt, R. and Krautscheid H., A novel copper-based MOF material: Synthesis, characterization and adsorption studies, Microporous Mesoporous Material, 142, 62-69, (2011).

[3] Volkringer, C., Loiseau, T., Guillou, N., Férey, G., Haouas, M., Taulelle, F., Elkaim, E. and Stock, N., High-throughput aided synthesis of the porous metal- organic framework- type aluminum pyromellitate, MIL- 121, with extra Carboxylic Acid functionalization, Inorganic Chemistry, 49, 21, 9852-9862, (2010).

[4] Tabatabaee, M., Sharif, M.A., Vakili, F. and Saheli, S., Hydrothermal synthesis and structural studies of a new coordination polymer of lanthanum(III) with benzene- 1 , 2, 4, 5- tetracarboxylic acid and 4, 4'bipyridine, Journal of Rare Earths, 27, 356-361, (2009).

[5] Qi, Y., Wang, Y., Hu, C., Cao, M., Mao, L. and Wang E., A new type of single- helix coordination polymer with mixed ligands, Inorganic Chemistry, 42, 25, 8519-8523, (2003).

[6] Gu, Z.G., Liu, Y.T., Hong, X.J., Zhan, Q.G., Zheng, Z.P., Zheng, S.R., Li, W.S., Hu, S.J. and Cai, Y.P., Construction of metalimidazole- based dicarboxylate networks with topological diversity: thermal stability, gas adsorption, and fluorescent emission properties, Crystal Growth Design, 12, 2178-2186, (2012).

[7] Vilela, S.M.F., Ananias, D., Fenandes, J.A., Silva, P., Gomes, A.C., Silva, N.J.O., Rodrigues, M.O., Tomé, J.P.C., Valante, A.A., Claro, P.R., Carlos, L.D., Rocha, J. and $\mathrm{Paz}$ F.A.A., Multifunctional micro- and nanosized metal- organic frameworks assembled from bisphosphonates and lanthanides, Journal of Materials Chemistry C, 2, 3311-3327, (2014).
University for the use of the Agilent Xcalibur Eos diffractometer (purchased under University Research Grant No. 2010.KB.FEN.13). The author also acknowledges to Balikesir University, Science and Technology Application and Research Center (BUBTAM) for the use of the Photoluminescence Spectrometer and thanks to Prof.Dr. Hulya KARA SUBASAT, Asst. Prof. Yasemin ACAR and Dr. M. Burak COBAN for their helpful and constructive suggestion.

[8] Yang, Y.S., Liu, M., Yang, Y.P., Jin, Q.H., Li, Z.F., Xue X.N., Zhang, Z.J. and Zheng, W.J., Synthesis, structures, luminescence and terahertz time-domain spectroscopy of seven lanthanide complexes with tetrakis $(\mathrm{O}$ isopropyl)methylenediphosphonate and 1, 10phenanthroline, Polyhedron, 93, 66-75, (2015).

[9] Xiaoyong, T., Shantang, Y., Ping, L., Ning, W. and Yingliang L., Hydrothermal synthesis and crystal structure study of two novel 3-D mellitates $\left\{\mathrm{Nd}_{2}\left[\mathrm{C}_{6}(\mathrm{COO})_{6}\right] \quad\left(\mathrm{H}_{2} \mathrm{O}\right)_{6}\right\}$ and $\left\{\mathrm{Ho}_{2}\left[\mathrm{C}_{6}(\mathrm{COO})_{6}\right]\left(\mathrm{H}_{2} \mathrm{O}\right)_{6}\right\}$, Journal of Rare Earths, 26, 6, 800-803, (2008).

[10] Guo, L., Wu, G. and Li H.H., Synthesis, crystal structures, thermal and luminescent properties of rare earth metal complexes with 1, 2, 4, 5- Benzenetetracarboxylic Acid, Journal of Chemical Crystallography, 42, 192-198, (2012).

[11] Sheldrick, G.M., Acta Crystallography, Section A, 64 , 112, (2008).

[12] Dolomanov, O.V., Bourhis, L.J., Gildea, R.J., Howard, J.A.K., Puschmann, H.J. Applied Crystallography, 42, 339 (2009).

[13] Spek, A.L., Acta Crystallography, Section D, 65, 148, (2009).

[14] MERCURY 1.4.2, Copyright from Cambridge Crystallography Data Center, (2001-2007).

[15] Wang, J.L., Hou, K.L., Xing, Y.H., Deng, Z.Y. and Shi, Z., Synthesis and characterization of two 3-D polymeric lanthanide complexes constructed from 1,2 , 4, 5-benzenetetracarboxylic acid, Journal of Coordination Chemistry, 64, 21, 37673780, (2011).

[16] Wang, J.L., Hou, K.L., Bai, F.Y., Xing, Y.H. and Shi Z., Hydrothermal synthesis, crystal structure, and photoluminescence of novel lanthanide metal organic frameworks constructed from 1, 4- benzene-dicarboxylic acid and 1, 2, 4, 5- benzenetetracarboxylic acid as ligands, Structural Chemistry, 23, 275-285 (2012).

[17] Acar, Y., Photoluminescence properties of $\mathrm{Gd}(\mathrm{III})$ and $\mathrm{Ce}(\mathrm{III})$ lanthanide based metal organic frameworks, Anadolu University Journal Of Science And Technology A Applied Sciences and Engineering, 17, 4, 754-765 (2016). 
[18] Marques, L.F., Correa, C.C., Garcia, H.C., Francisco, T.M., Ribeiro, S.J.L., Dutra, J.D.L., Freire, R.O. and Machado, F.C., Theoretical and experimental spectroscopic studies of the first highly luminescent binuclear hydrocinnamate of Eu (III), Tb (III) and Gd (III) with bidentate 2, 2'- bipyridine ligand, Journal of Luminencence, 148, $307-$ 316 (2014).

[19] Zhou, X., Zhao, X., Wang, Y., Wu, B., Shen, J., Li, L. and Li, Q., Eu (III) and Tb (III) complexes with the nonsteroidal antiinflammatory drug Carprofen: Synthesis, crystal structure and photophysical properties, Inorganic Chemistry, 53, 12275-12282, (2014).

[20] Li, X.L., Chen, C.L., Kang, J.L., Wang, A.L., Wang, P.Y. and Xiao, H.P., Synthesis, crystal structures and near-infrared luminescent properties of three lanthanide-based enantiomeric pairs, Inorganica Chimica Acta, 408, 78-83, (2013).

[21] Chandra, D., Kasture, M.W. and Bhaumik, A., A new microporous MOF material based on $\mathrm{Zn}$ (II) -polycarboxylate coordination polymer synthesized with the aid of 1,6 diaminohexane as template, Microporous and Mesoporous Material, 116, 204-209, (2008).

[22] Jiang, Y.S., Yu, Z.T., Liao, Z.L., Li, G.H. and Chen, J.S., Syntheses and photoluminescent properties of two uranyl- containing compounds with extended structures, Polyhedron, 25, 1359-1366, (2006).

[23] Zhang, Y., Ji, J., Fu, J.D., Cheng, J.W. and Wen, Y.H., Cooperative assembly of coexistent lanthanide- carboxylate chain and layer in a $(4,6)$ - connected network, Inorganic Chemistry Communications, 35, 181-185, (2013).

[24] Saha, R., Goswami, S., Biswas, S., Seele, I.M., Dey, K., Jana, A.D. and Kumar S., A dynamic metal- organic supramolecular host based on weak p- stacking interactions incorporating 2D water- chloride- methanolic supramolecular sheet, Inorganica Chimica Acta A , 423, 123-132, (2014).

[25] Dang, S., Yu, J., Yu, J., Wang, X., Sun, L.,
Feng, J., Fan, W. and Zhang, H., Novel Holmium (Ho) and Praseodymium (Pr) ternary complexes with fluorinated- ligand and 4, 5- diazafluoren- 9- one, Material Letters, 65, 1642-1644, (2011).

[26] Sun, L., Qiu, Y., Liu, T., Zhang, J.Z., Dang, S., Feng, J., Wang, Z., Zhang, H. and Shi L., Near infrared and visible luminescence from xerogels covalently grafted with lanthanide $\left[\mathrm{Sm}^{3+}, \mathrm{Yb}^{3+}, \mathrm{Nd}^{3+}, \mathrm{Er}^{3+}, \mathrm{Pr}^{3+}, \mathrm{Ho}^{3+}\right] \beta-$ diketonate derivatives using visible light excitation, ACS Applied Material and Interfaces, 5, 9585-9593, (2013).

[27] Sun, L., Qiu, Y., Liu, T., Peng, H., Deng, W., Wang, Z. and Shi, L., Visible-light sensitized sol-gel-based lanthanide complexes ( $\mathrm{Sm}, \mathrm{Yb}$, Nd, Er, Pr, Ho, Tm): microstructure, photoluminescence study, and thermostability, The Royal Society of Chemistry Advances, 3, 26367-26375, (2013).

[28] Moore, E.G., Samuel, A.P.S. and Raymond, K.N., From antenna to assay: Lessons learned in lanthanide luminescence, Accounts of Chemical Research, 42, 4, 542-552, (2009).

[29] Dang, S., Sun, L.N., Zhang, H.J., Guo, X.M., Li, Z.F., Feng, J., Guo, H.D. and Guo Z.Y., Near-infrared luminescence from sol- gel materials doped with Holmium (III) and Thulium (III) complexes, Journal of Physical Chemistry C , 112, 13240-13247, (2008).

[30] Kawa, M. and Fréchet, J.M.J., Selfassembled lanthanide- cored dendrimer complexes: Enhancement of the luminescence properties of lanthanide ions through site-isolation and antenna effects, Chemistry of Materials, 10, 286-296 (1998).

[31] Coban, M.B., Amjad, A., Aygun, M. and Kara, H., Sensitization of $\mathrm{Ho}^{\text {III }}$ and $\mathrm{Sm}^{\text {III }}$ luminescence by efficient energy transfer from antenna ligands: Magnetic, visible and NIR photoluminescence properties of $\mathrm{Gd}^{\mathrm{III}}$, $\mathrm{Ho}^{\text {III }}$ and $\mathrm{Sm}^{\mathrm{III}}$ coordination polymers, Inorganica Chimica Acta, 455, 25-33 (2017).

\section{Supplementary material}

Crystallographic data for the structural analysis have been deposited with the Cambridge Crystallographic Data Centre, CCDC No. 1565818 for complex 1. Copies of the data can be obtained free of charge from the Director, CCDC, 12 Union Road, Cambridge CB2 1EZ, UK (fax: +44-1223-336-033; e-mail: deposit@ccdc.cam.ac.uk or www: http://www.ccdc.cam.ac.uk). 